Nadwa : Jurnal Pendidikan Islam

Vol. 13, No.2 (2019)

Accredited by Ristekdikti based on Decree No. 51/E/KPT/2017

DOI : $10.21580 / n w .2019 .13 .2 .4995$

\title{
Needs Analysis of The Islamic Arabic Material Teaching Based on Communicative for University Students
}

\author{
Dwi Mawanti \\ UIN Walisongo, Indonesia \\ dwi.mawanti@walisongo.ac.id
}

\begin{abstract}
Teaching materials are one of the important components needed in the learning process. The Arabic language course program is a compulsory course for second semester students department in Islamic Education (PAI) Walisongo State Islamic University (UIN) Semarang. This study aims to describe the students' needs for communicative Arabic based teaching materials for students department in Islamic education at the Faculty of Tarbiyah and Education (FITK) UIN Walisongo Semarang. The results of this study indicate that $41.56 \%$ of students require renewal of Arabic course material developed with communicative principles that contain topics of Islamic education in accordance with the department of Islamic education. these materials include Quran-Hadith, Aqedah, Tafsir, Sufism, Fiqh and Islamic History..
\end{abstract}

Keywords: Arabic teaching materials, Islamic sciences, communicative based.

\begin{abstract}
Abstrak
Bahan ajar adalah salah satu komponen penting yang dibutuhkan dalam proses pembelajaran. Program kursus Bahasa Arab adalah kursus wajib untuk mahasiswa semester dua di jurusan Pendidikan Agama Islam (PAI) Universitas Islam Negeri (UIN) Walisongo Semarang. Penelitian ini bertujuan untuk mendeskripsikan kebutuhan siswa akan bahan ajar Bahasa Arab berbasis komunikatif untuk siswa jurusan pendidikan agama islam di Fakultas Ilmu tarbiyah dan kependidikan (FITK) UIN Walisongo Semarang. Hasil penelitian ini menunjukkan bahwa $41,56 \%$ siswa membutuhkan pembaharuan materi kursus bahasa Arab yang dikembangkan dengan prinsip-prinsip komunikatif yang berisi topik-topik pendidikan Islam sesuai dengan departemen pendidikan Islam. bahan-bahan ini termasuk Quran-Hadits, Akidah, Tafsir, Sufisme, Fiqh dan Sejarah Islam.
\end{abstract}

Kata Kunci: bahan ajar bahasa Arab, ilmu-ilmu keislaman, berbasis komunikatif.

ISSN 1979-1739 (P) ; ISSN 2502-8057 (E).

(C) 2019 Nadwa : Jurnal Pendidikan Islam | UIN Walisongo.

Accredited by Ristekdikti based on Decree No. 51/E/KPT/2017

http://journal.walisongo.ac.id/index.php/nadwa 


\section{Introduction}

A language is tool for gaining knowledge of Islam, especially to master the meaning of the Qur'an and the hadith. Further Islamic scholars can understand books in various treasures of Islamic disciplines, such as myths, Islamic cultural history, Aqidah, morals and more. In modern times there are many books that integrate Islam and science and social science, and these books are widely written by Middle Eastern scholars such as Egypt, Syria, Lebanon, and North African countries. Thus the main source of references to Islam is written in Arabic. To master Islam more deeply, in addition to the science of turath (classical science), the Islamic students of PAI must also be able to communicate in Arabic.

The Arabic language is taught in several FITK department including PAI department is still using the same material teaching as other department. In FITK there are no Arabic languagespecific materials or materials for each major, either Arabic I and Arabic II. This is in contrast to the PAI major where these students of PAI need to have good Arabic language skills, as all PAI students still tend to be passive.

Wainwright stated that vocabulary is a very important factor in reading2. The more a person masters the vocabulary the more he understands the reading. Furthermore, Tarigan states that the

1 Observation of learning in the lecture hall of the first Arabic course, 28 October 2019

2Wainwright, Gorden. Speed Reading Better Recalling ManfaatTeknikTeknik Teruji untuk Membaca Lebih Cepat dan Mengingat secara Maksimal. Jakarta: Remedia Pustaka Utama,2007 
quality of a person's language skills depends on the quantity and quality of his vocabulary3. The more vocabulary a person has, the more likely a person is skilled in the language.

Several educational institutions or universities in the world have tried to teach Arabic through Islamic religion lecture material. So to master Arabic in the PAI major by the learning objectives, it is necessary to have a combination of Arabic language and Islamic subjects such as; interpretation, hadith, fiqh and Ushul Fiqh, Aqidah and Islamic History.

Learning Arabic in each major should ideally be taught communicatively to enable students to master the four language skills (maharat al-istima ', al-kalam, al-qira'ah, and al-kitabah) functionally and proportionally4. This is because Arabic is not merely a receptive function, namely as a medium for understanding (al-fahm) what can be heard, news, text, reading, and discourse, but also function productively or expressively, that is to understand (al-ifham) others through oral and written communication.

In major of PAI, Arabic becomes a very important subject because it becomes a pillar for religious courses in the study program. A qualified graduate of PAI major is one of the barometers that can mastery the basics of Arabic because, in every religious lesson taught at the junior high school and senior high school level many use terms derived from Arabic, even many

3Tarigan, Henry Guntur. Pengajaran Kosakata. Bandung: Angkasa, 2011 4 Abdul Wahab, Muhbib. Epistimologi Dan Metodologi PembelajaranBahasa Arab. Jakarta: Lembaga Penelitian Universitas Islam Negeri Syarif Hidayatullah Jakarta,2008 
verses of the Qur'an and The hadith is in the textbooks which the teacher who teaches must be able to analyze the verse or hadith and know the meaning of the words of the verse or the hadith in earnest.

So one of the learning components that can support success is Teaching Materials. PAI Arabic teaching materials for students until now have not been communicative based5. The teaching material has not been designed for the needs of PAI students. This resulted in learning Arabic at major of PAI felt difficult, ineffective and tended to be boring. While the experience of students in Arabic lectures is around 16 meetings with 2 SKS with reading texts in textbooks and the material is still quite far related to the department.

Therefore, the researcher wants to describe communicativebased Arabic teaching material for PAI students as a product that suits the needs of students, describes the objectives to be achieved, overcomes student difficulties.

\section{Methode}

This research is a qualitative descriptive study with a survey method conducted in November-December 2019 in the Department of Islamic Education UIN Walisongo Semarang. The study population was all third-semester students department in PAI UIN Walisongo who took 120 Arabic courses, 75 students were randomly selected.

5 Interview with the Chair of the Department of PAI at FITK on 5 November 2019 
Data collection techniques by interview, observation, and questionnaire. In a questionnaire. Observation sheets are used to obtain data about learning activities in Arabic courses. An open questionnaire is used to obtain data about learning resources that have been used by students, the needs of teaching materials desired by students and to find out the material needed by students. Research data were analyzed. Descriptive qualitative.

\section{Communicative Approach}

Communicative approach is an approach that aims to make communicative competence as the goal of language learning, also develops procedures for learning that include four language skills namely listening, reading, speaking and writing, acknowledging and respecting language dependency. In line with the above opinion, Sumardi explained that this approach was prepared on the basis of the learner's functions and needs, in the hope that learners could use language to communicate in real situations and not artificial communication6.

The purpose of the communicative approach in teaching language is to train students about using language automatically and creatively and act only on mastering the rules. And the manifestation of experience in this approach is the use of a series of new concepts related to language, and the learning psychology of the learners is well determined by the features of the communication approach.

6Mulyanto Sumardi, Berbagai Pendekatan dalam Pengajaran Bahasa dan Sastra, Jakarta: Pustaka Sinar Harapan, Cet. ke-2, 1996 
This communicative approach basically aims to form communication competencies (communicative competence) in learners. Communication competence is essentially a deep knowledge of someone about when (when) or not should (when not) talk, what should be talked about (what), with whom they talk (with whom), when (when) or where (where) the conversation happened, and in what way the conversation should be expressed (manner) 7 .

Kridalaksana suggested that communicative competence is the ability of linguists to use language that is socially acceptable and adequater. The communicative approach does not deny the existence of language structures in total learning, but this approach gives the role of communicative elements more than the structural elements in language learning. Tarigan explained that this approach was fully oriented towards the function of language as a means of communication between people.

The language functions meant in the communicative approach are nothing but the aim of learning to develop the communicative competence of the learner, so that language learning using the communicative approach is considered more relevant to the language function itself, namely for communication between people, in other words, that the development of learning Today's language should be directed towards active learner language skills. This shows that learning

7Rusydi Ahmad Thu'aimah dan Mahmud Kamil al-Naqah, 2006, Ta'lim alLughah Ittishaliyan, Kairo: Esisko,2006 8Harimurti Kridalaksana, Kamus Linguistik, Jakarta: PT Gramedia Pustaka Utama, 1993 
must be centered on the learner, ie the proportionality of the role between learners and teachers will be more the role of learning activities in language learning, therefore, learners are no longer waiting, accepting let alone just memorizing the rules of language taught without exploration and construction of the learners themselves towards the knowledge and practice of language being taught. But all of that must be supported by teaching materials that are following the communicative approach, both in the form of text (dialogue and free reading), assignments (telling stories about the daily lives of learners, retelling the results of a trip to a place with the editor's language and others) and authentic

In the communicative approach that becomes the reference is the learner's needs and language function that aims so that learners can communicate in real situations9. Naturally, the main reference for each unit of study is the function of language and not grammar. Grammar is a means to carry out communication purposes not as learning objectives 10 . So that in the learning process, the role of learners is more prominent.

The characteristics of the communicative approach, namely11:

$\checkmark$ Give priority to the true meaning rather than grammatical.

${ }_{9}$ Nur Laila, Pengembangan Bahan Ajar Bahasa Arab Berbasis Komunikatif Untuk Mahasiswa Program Studi Keperawatan Stikes Purna Bhakti Husada Batusangkar, Ta'dib Vol.14 No 2, 2011

10Henry Guntur Tarigan, Pengajaran Kompetensi Komunikatif, Bandung: Angkasa, 1990.

11Mansoer Pateda, 1991, Linguistik Terapan, Flores: Nusa Indah, Cet. ke-1, 1991. 
$\checkmark$ The existence of functional communication activities and social interactions that are interrelated.

$\checkmark$ Learning is oriented towards the acquisition of communicative competence, not grammatical accuracy (understanding to be applied in everyday life).

$\checkmark$ Learning is directed at the modification and improvement of students in finding language rules through language activities.

$\checkmark$ Learning material departs from the analysis of language learning needs

In the communicative approach, exercises and learning activities are relatively unrestricted, as long as these exercises can help learners achieve communicative goals and can involve learners in communication, and must use communicative processes such as information sharing, negotiation, and interaction. Communicative activities can be oral or written. Verbal activities can take the form of class meetings, debates, simulations or experiences. While writing activities can be in the form of announcements, advertisements or journals.

From the explanation above, it can be concluded that the nature of the communicative approach in language learning is an approach that views language as a social phenomenon that functions as a communication tool between individuals in society with various contexts that surround it 12 . This approach emphasizes the function and meaning as well as in language and

12Jack C Richard and Theodore S. Rodgers, Approaches and Methods In Language Teaching, New York: Cambridge University Press, 1992. 
is not focused on grammar that is often not related to the meaning to be expressed

This approach teaches how a person has communicative competence to be able to use language by its function as a communication tool.

\section{Teaching materials}

Teaching material is a set of learning material or substance that is arranged systematically and displays in full the competencies that students will master in learning activities. Teaching materials have a high contribution to the achievement of learning objectives 13. Therefore, teaching materials must be well designed by the objectives to be achieved.

Teaching materials are all forms of material used to help teachers, lecturers or instructors in carrying out learning activities in class. Teaching materials can also be interpreted with a set of materials arranged systematically to create an atmosphere that allows learners to learn. This teaching material is prepared based on a communicative approach which is to develop communicative competencies in learners in the domain of listening, speaking, reading, or writing

In the communicative approach that becomes the reference is the learner's needs and language function that aims to enable learners to communicate in real situations. Naturally, the main reference for each unit of study is the function of language and

13Nasution, Berbagai Pendekatan dalam Proses Belajar dan Mengajar, Jakarta: Radar Jaya Offset, 1992 
not grammar. Grammar is a means to carry out communication purposes not as learning objectives. So that in the learning process, the role of learners is more prominent.

Teaching materials that are prepared based on communicative approaches prioritize communication principles, training principles, and meaningfulness. So learning can involve learners in the use of meaningful and authentic language 14.

The types of teaching materials in the form of 1) printed teaching materials (printed), including handouts, books, modules, posters, brochures, student worksheets (LKS), wallcharts, photos or drawings, and leaflets; 2) audio teaching materials such as cassettes, radios, vinyl records, and audio compact disks; 3) audiovisual teaching materials such as video compact discs, films; and 4) interactive multimedia teaching materials (interactive teaching material) such as CAI (Computer Assisted Instruction), interactive learning multimedia compact disk (CD), and web-based teaching materials (web-based learning materials)

Teaching materials also have function as an evaluation tool for achieving learning outcomes. According to Prastowo stated that the function of teaching materials can be divided into two types, namely the function for educators and the function for students 15 .

$\checkmark$ The function of teaching materials for educators, including: Save time teaching educators; Change the role of the

14 Ahmad Fuad Effendi, 2005, Metodologi Pengajaran Bahasa Arab, Malang: Misyarakat, 2005.

15 Andi Prastowo, Panduan Kreatif Membuat Bahan Ajar Inovatif. Yogyakarta: Diva Press, 2011. 
educator from a teacher to become a facilitator; Improve the learning process to be more effective and interactive; As a guide for educators who will direct all their activities in the learning process and is a substance of competence that should be taught to students; As an evaluation tool for achievement or mastery of learning outcomes.

$\checkmark$ The function of teaching materials for students, including: Students can learn without having to have educators or other student friends; Students can learn whenever and wherever they want; Students can learn at their own pace; Students can learn in their own chosen order; Helping potential students to become independent students.

As a guide for students who will direct all their activities in the learning process and is a substance of competence that should be learned or mastered. Good teaching materials include learning instructions, competencies to be achieved, lesson content, supporting information, exercises, work instructions, evaluation and response to evaluation results. For students teaching materials can help participants to become independent learners and can be used to measure competencies that have been mastered. The design of teaching materials becomes very important in the learning process. Teaching material developed must be able to increase the motivation and effectiveness of its users.

\section{Arabic and Islamic Sciences}

Many educational institutions and universities now call for Arabic to be taught in the Islamic sciences. The goal is the rules 
of language as well as being applied to the subtlety of understanding meaning.

Ulama used to write many books of religious knowledge by always linking to the rules of language such as the provisions of $n a h w u$, saraf, bayan, and ma'aniy16. This is often found in the explanation of 'irab in books such as commentaries, hadiths and also fiqh, especially when the meaning of the Qur'an and the Prophet's hadith is explained.

Singhal, citing several opinions, put forward several advantages of language learning in an integrated manner17:

$>$ Facilitate learning in both fields of science, because the goal is to teach students to read and write, even to use reading and writing as a tool for iktisab al-lughah (obtaining language) 18 .

$>$ Saving time, especially for adults (students). Students immediately get a combination of learning to read with understanding the material and even at the same time get the language (talent), because they have memorized the verses of the Qur'an and the hadith of the Prophet found in the learning curriculum. That is, verses or hadith or certain rules that have been memorized directly applied to the rules of language and understood their meaning

16Iskandar wassid, Strategi Pembelajaran Bahasa, Rosdakarya: Bandung, 2008.

${ }_{17}$ Singhal, M. The Internet and foreign language education: Benefits and challenges. The internet TESL journal, 3(6), 1997

18 Ayuba, M. A. . The Arabic language: Its relevance to Nigerian development. European Scientific Journal, 8(26).2012 
$>$ The realization of integration between aspects of language experience with aspects of knowledge can display material that has been obtained and at the same time practice language which includes listening, reading and writing.

$>$ Improve the ability to remember what has been learned from the rules of language 19 .

$>$ Increasing the urge to learn languages, especially if students feel that the language material presented is according to their needs.

$>$ It makes students easy and fluent in reading Arabic (AlQur'an, Hadith and other texts).

$>$ There is confidence in the students themselves about their ability to learn languages.

Developing integrity planning between Arabic and Islamic science is an important learning program carried out by the Department of Islamic Education20. This is based on several reasons:

$\checkmark$ Arabic is the language of the Qur'an and at the same time the language of religion for all Muslims in the world. The Qur'an is read in this language and prayers are carried out in this language as well, where these two worship services are illegitimate in their translation.

19 Ayish, M. I. .Beyond western-oriented communication theories a normative Arab-Islamic perspective.Javnost-The Public, 10(2), 2003 20 Maamouri, M. Language Education and Human Development: Arabic Diglossia and Its Impact on the Quality of Education in the Arab Region.1998 
$\checkmark$ Al-Qur'an which is the main way of life of Muslims revealed in Arabic and words in this language have broad and detailed meanings and sometimes is not represented by words in Indonesian.

$\checkmark$ Vocabulary and breadth of the meaning of mufradat will be obtained from Arabic books. For example, the word ذذذذ which is often given the meaning of "going" is found other meanings in Islamic books such as: "opinion", "missing or missing".

$\checkmark$ Learning linguistics such as nahwu and nerve lacks positive value without being applied in reading texts such as Arabic books, verses of the Qur'an and hadith.

$\checkmark$ Arabic styles will stick in the minds of students either in understanding the meaning of texts or in writing with Arabic culture after being read over and over again.

$\checkmark$ For Muslims, including in Indonesia, who encourage to learn Arabic is because they want to deepen the knowledge of the Islamic religion.

$\checkmark$ Combining aspects of Islamic science with Arabic for nonArabic mutual support to study these two fields of science.

\section{Result}

Based on observation was done during Arabic lectures, information was obtained that not all students can focus on learning activities. More than $40 \%$ of students have not been able to participate actively in the learning process, this is because teaching materials are not interestng. The absence of communicative-based Islamic Arabic teaching materials has made students not active in the learning process of Arabic. 
Because students do not have the readiness so learning tends to go in one direction, in the discussion and question and answer session, not all students can participate.

Learning resources used by students in lectures so far are in the form of textbooks issued by PIB UIN Walisongo Semarang intended for all department at UIN Walisongo so that the teaching materials are still very general and have not discussed in-depth Islamic material for PAI students.

Based on the questionnaire distributed to the students, it was obtained that the students wanted teaching materials that were developed independently by lecturers who were able to use language that was easy for students to understand, concise, and there were practice questions related to four skills (maharah\} with Islamic material for PAI student.

While the type of teaching materials desired by students $41.56 \%$ of students wanted a communicative Arabic Islamic teaching material. Teaching materials have a different character from reference books in general. The preparation of teaching material is adjusted to the curriculum. Written and designed based on the needs of students, using communicative language, referring to the competencies that must be achieved, for the instructional process and having a feedback mechanism from students. In that teaching material can develop the potential of students to become independent learners.

\section{Discussion}

In line with the purpose of the study is to analyze the needs of communicative-based Arabic Islamic teaching materials. The 
results of the analysis of the needs analysis of PAI students of UIN Walisongo Semarang they can be identified that lecturers and students strongly agree and support the creation and development of communicative-based Arabic teaching materials in Arabic courses for students department in PAI UIN Walisongo Semarang. Based on the findings obtained from the results of the analysis, the authors found the need for improvement in the quality of learning Arabic in the Department of Islamic Education, UIN Walisongo, Semarang. The Department of Islamic Education must improve the lecturers ability to designing and implementing Arabic learning activities as well as the procurement and addition of teaching materials that can increase the interest and motivation of PAI students. This can be done by providing knowledge and abilities to lecturers in designing and implementing activities in learning Arabic, as well as developing communicative-based teaching materials 21.

Based on the problems at the analysis stage that have been explained in the research results, sown that in the Arabic learning process lecturers and students have not been supported with teaching specific material.22 The authors must develop products in the form of communicative based Arabic teaching materials.

21Wekke, I. S., \&Lubis, M. A.. A Multicultural approach in Arabic language teaching: creating equality at Indonesian pesantren classroom life. Sosiohumanika, 1(2). 2008

22 Taha-Thomure, H.The status of Arabic language teaching today.Education, Business and Society: Contemporary Middle Eastern Issues. (2)1.2008 
The findings in this article practically can be followed up by the writer and lecturer in fixing teaching materials used by Arabic lecturers. Lecturers must also continue to explore the potential and knowledge of Islam that is worthy of integration in learning Arabic so that learning becomes meaningful, enjoyable, and sustainable. Without a change in lecturer attitudes, the application of communicative-based teaching materials in the PAI UIN Walisongo department will not succeed.

The material expected by students in the teaching material being developed is about Islamic material on a communicative based. Students assume that Islamic material needs to be taught in Arabic communicatively in four abilities (maharoh). This at least has this goal, including those that need to be emphasized by the Islamic Religious Education Study Program for students, because they will become teachers of Islamic religious knowledge and education in madrasah and schools. In essence, to achieve these objectives cannot be separated between learning interpretation with learning Arabic. Modern Arabic learning also emphasizes correcting the pronunciation and pronunciation of the correct Arabic alphabet so that students can listen and then communicate in this language with others and with native speakers.

The teaching materials needed to refer to Islamic sciences namely the Quran Hadith, Akiqah, Tafsir, Sufism, Fiqh and Islamic History then the material is taught using the principles of the communicative approach. The following outlines the characteristics of communicative-based teaching materials needed. 
$\checkmark$ The reading method. This method emphasizes the ability of students to read and understand the content of text which in Arabic is called "understanding". At the PAI study program student level, it can be adequate at the second level, comprehension. Because the levels above, such as analyzing sentences and evaluating writing, are more appropriate for students to study Arabic.

$\checkmark$ The conversation method. This method contains a conversation between two or more people. The application of this method is intended so that students are accustomed to actively verbally communicating. Of course, related to Islamic material.

$\checkmark$ The listening Method. This method trains students to listen to Islamic teaching materials. After that students can actively communicate re-tell the material both verbally and in writing.

$\checkmark$ The writing Method. This method focuses on the ability of students to re-communicate Islamic Arabic teaching materials in writing.

To increase the using of new mufradat relating to Islamic material, it is given at the beginning of each lesson so that students do not experience difficulties in understanding the text in the material qiraaah, kalam, istima, and kitabah; and we are. Likewise in every implementation, every method used is multiplied tadribat or exercises in each expert to evaluate the communicative Arabic ability of PAI students. 
Dwi Mawanti| 269

\section{Conclusion}

Students strongly agree and support the creation and development of communicative-based Arabic teaching materials in Arabic courses for students department in PAI UIN Walisongo Semarang. The teaching materials needed to refer to student needs that include in material islamic teaching namely the Quran Hadith, Akiqah, Tafsir, Sufism, Figh and Islamic History then the material is taught using the principles of the communicative approach.

\section{References}

Abdul Wahab, Muhbib. Epistimologi Dan Metodologi Pembelajaran Bahasa Arab. Jakarta: Lembaga Penelitian Universitas Islam Negeri Syarif Hidayatullah Jakarta. 2008

Ayish, M. I. (2003). Beyond western-oriented communication theories a normative Arab-Islamic perspective. Javnost-The Public, 10(2), 79-92.

Ayuba, M. A. (2012). The Arabic language: Its relevance to Nigerian development. European Scientific Journal, 8(26).

Effendi, Ahmad Fuad, 2005, Metodologi Pengajaran Bahasa Arab, Malang: Misykat,hal, 2005

Henry Guntur Tarigan, Pengajaran Kompetensi Komunikatif, Bandung: Angkasa. 1990.

Iskandarwassid, Strategi Pembelajaran Bahasa, Rosdakarya. 2008.

Kridalaksana, Harimurti, Kamus Linguistik, Jakarta: PT Gramedia Pustaka Utama, 1993.

Laila, Nur, Pengembangan Bahan Ajar Bahasa Arab Berbasis Komunikatif UntukMahasiswa Program Studi Keperawatan Stikes Purna Bhakti Husada Batusangkar, Ta'dib Vol.14 No 2, 2011 
M, Maamouri, (1998). Language Education and Human Development: Arabic Diglossia and Its Impact on the Quality of Education in the Arab Region. 2(1)

Nasution, S, Berbagai Pendekatan dalam Proses Belajar danMengajar, Jakarta: Radar Jaya Offset, 1992.

Pateda, Mansoer, Linguistik Terapan, Flores: Nusa Indah, Cet. ke1.1991

Prastowo, Andi. Panduan Kreatif Membuat Bahan Ajar Inovatif. Yogyakarta: DivaPress.2011.

Richard, Jack C dan Theodore S. Rodgers, Approaches and Methods In Language Teaching, New York: Cambridge University Press. 1992

Singhal, M. The Internet and foreign language education: Benefits and challenges. The internet TESL journal, 3(6), 107. 1997

Sumardi, Mulyanto, Berbagai Pendekatan dalam Pengajaran Bahasa dan Sastra, Jakarta: Pustaka Sinar Harapan, Cet. ke-2,1996.

Taha-Thomure, H.. The status of Arabic language teaching today. Education, Business and Society: Contemporary Middle Eastern Issues. (2)1 2008

Tarigan, Henry Guntur. Pengajaran Kosakata (EdisiRevisi). Bandung: Angkasa. 2011

Thu'aimah, Rusydi Ahmad dan al-Naqah, Mahmud Kamil, Ta'lim alLughah Ittishaliyan, Kairo: Esisko, 2006

Wainwright, Gorden. Speed Reading Better RecallingManfaat Teknik-Teknik Teruji untuk Membaca Lebih Cepat dan Mengingat secara Maksimal. Jakarta: remedia Pustaka Utama.2007 